Section Editor

Robert C. Griggs, MD
Editors' Note: In response to "Evidence-based guideline: Pharmacologic treatment of chorea in Huntington disease," Dr. Suchowersky comments on the need for caution in prescribing tetrabenazine with other medications metabolized by cytochrome P450. Authors Armstrong and Miyasaki encourage clinicians to consult prescribing details before starting any medications. In reference to "Antiplatelets vs anticoagulation for dissection: CADISS nonrandomized arm and meta-analysis," Dr. Caplan points out that most recurrent strokes in patients with cervical dissections occur within 7 days, while the mean time of treatment after symptom onset in this study was 10.8 days. The authors respond that they are looking at the acute phase after cervical dissection in their ongoing randomized arm.

Megan Alcauskas, MD, and Robert C. Griggs, MD

EVIDENCE-BASED GUIDELINE: PHARMACOLOGIC TREATMENT OF CHOREA IN HUNTINGTON DISEASE: REPORT OF THE GUIDELINE DEVELOPMENT SUBCOMMITTEE OF THE AMERICAN ACADEMY OF NEUROLOGY

Oksana Suchowersky, Alberta, Canada: I read with interest the recent guideline on the treatment of chorea in Huntington disease ${ }^{1}$ and the recommendation of using up to $100 \mathrm{mg}$ of tetrabenazine daily. The authors reviewed side effects of this medication including parkinsonism and depression. However, they did not mention that tetrabenazine is metabolized by cytochrome P450 (CYP2D6). Care needs to be taken when tetrabenazine is used with antidepressants such as paroxetine and fluoxetine and other drugs that are inhibitors of CYP2D6. Because individuals with Huntington disease are often treated with these antidepressants, the dose of tetrabenazine should be decreased by $50 \%$. $^{2}$ Secondly, some individuals metabolize tetrabenazine faster than others. If doses more than 50 $\mathrm{mg}$ per day are being considered, it is recommended that patients undergo testing for CYP2D6 metabolizer status to determine whether they are slow metabolizers. ${ }^{3}$ Dosages above $50 \mathrm{mg}$ per day in both of these circumstances will increase the risk of side effects.

Author Response: Melissa J. Armstrong, Baltimore; Janis Miyasaki, Toronto: We thank Dr. Suchowersky for her comments on the treatment of chorea in
Huntington disease guideline. ${ }^{1}$ Although we did not address tetrabenazine (TBZ) metabolism in the evidence section of the guideline text, we did refer to this in the clinical context: "US TBZ prescribing information recommends genotyping for CYP2D6, the enzyme responsible for metabolizing TBZ, prior to TBZ use. Whether this advice is followed clinically is unknown. Possible interactions with other medications metabolized by the CYP2D6 system, such as fluoxetine or paroxetine, should be considered during TBZ dosing." The American Academy of Neurology guideline development process is intended to provide a formal assessment of the strength of the evidence in response to a specific question and cannot serve as the sole reference for clinicians considering prescribing any particular agent. Dosing recommendations are based on the evidence formally reviewed. Thus, some details—such as those mentioned by Dr. Suchowersky — cannot be fully captured in guideline publications. We agree with her points and encourage clinicians to consult prescribing information and other resources before choosing the best approach and dosage for their individual patients.

(C) 2013 American Academy of Neurology

1. Armstrong MJ, Miyasaki JM. Evidence-based guideline: pharmacologic treatment of chorea in Huntington disease: report of the Guideline Development Subcommittee of the American Academy of Neurology. Neurology 2012;79:597-603.

2. Guay D. Tetrabenazine, a monoamine-depleting drug used in the treatment of hyperkinetic movement disorder. Am J Geriatr Pharmacother 2010;8:331-373.

3. Tetrabenazine (Xenazine tablets) [package insert]. Mississauga, Canada: Biovail Corporation; 2008.

\section{ANTIPLATELETS VS ANTICOAGULATION FOR DISSECTION: CADISS NONRANDOMIZED ARM AND META-ANALYSIS}

Louis R. Caplan, Boston: The Cervical Artery Dissection in Stroke Study (CADISS-NR) trial concluded that there was no difference in secondary stroke prevention provided by antiplatelet and anticoagulant agents in patients with carotid or vertebral artery dissections. ${ }^{1}$ It is important to note that the mean time of treatment after symptom onset was 10.8 days (SD 7.0, range $1-31$ days) in this study.

Extensive published data ${ }^{2,3}$ and my personal experience show that most strokes develop within the first 7 days after brain ischemia and the rate of stroke 
thereafter is very low. In addition, strokes are uncommon in patients whose presentation does not include brain ischemia (neck pain, Horner syndrome, compression of nerve roots, or lower cranial nerves). These patients were included in the trial. In CADISS-NR, only 2 patients had strokes within 3 months.

In the meta-analysis included in the report, almost all of the patients were enrolled beyond 5 days after onset. Physicians must not take the results of this trial and the meta-analysis to conclude anything about treatment during the very acute period after brain symptom onset. This time period was not a part of the trial or the meta-analysis. When brain infarction develops in the acute stage, it is almost always explained by embolism of red erythrocyte-fibrin thromboemboli. ${ }^{4}$ This pathogenesis would predict that acute anticoagulation would be more effective than antiplatelets during the first week and experience has shown that acute anticoagulation is effective. ${ }^{5}$

Author Response: Hugh S. Markus, London: Dr. Caplan raises an important point: Some studies suggest that the risk of recurrent stroke in patients with cervical dissection is highest in the first few days after initial clinical symptoms. For this reason, the ongoing randomized arm of CADISS is recruiting patients within 7 days of symptom onset. The nonrandomized arm, the results of which are included in our current report, included patients who were ineligible for the randomized arm. Fifty-three of the 88 patients were included in the nonrandomized-rather than the randomized — arm because they were recruited later than 7 days after first symptoms. However, even in the remaining 35 (with some recruited on the first day after presentation), the risk of recurrent stroke was not high.

Convincing arguments can be made as to whether anticoagulants or antiplatelets may be more effective in preventing recurrent stroke in cervical dissection. However, whether anticoagulants or antiplatelets will be more effective during the acute phase can only be answered by randomized trials such as CADISS.

(C) 2013 American Academy of Neurology

1. Kennedy F, Lanfranconi S, Hicks C, et al; on behalf of the CADISS Investigators. Antiplatelets vs anticoagulation for dissection: CADISS nonrandomized arm and meta-analysis. Neurology 2012;79:686-689.

2. Biousse V, D'Anglejan-Chatillon J, Toboul PJ, Amarenco P, Bousser MG. Time course of symptoms in extracranial carotid artery dissections: a series of 80 patients. Stroke 1995;26: 235-239.

3. Beletsky V, Nadareishvili Z, Lynch J, Shuaib A, Woolfenden A, Norris JW. Cervical arterial dissection: time for a therapeutic trial? Stroke 2003;34:2856-2860.

4. Baumagartner RW, Bogousslavsky J. Clinical manifestations of carotid dissection. In: Baumgartner RW, Bogousslavsky J, Caso V, Paciaroni M, editors. Handbook on Cerebral Artery Dissection. Basel: Karger; 2005:70-76.

5. Schievink WI. The treatment of spontaneous carotid and vertebral artery dissections. Curr Opin Cardiol 2000;15: 316-321.

\section{Neurology ${ }^{\circledR}$ WriteClick: Join the Debate!}

The editors encourage comments about recent articles through WriteClick:

Go to www.neurology.org and click on the "WriteClick" tab at the top of the page. Responses will be posted within 72 hours of submission.

Before using WriteClick, remember the following:

- WriteClick is restricted to comments about studies published in Neurology within the last eight weeks

- Read previously posted comments; redundant comments will not be posted

- Your submission must be 200 words or less and have a maximum of five references; reference one must be the article on which you are commenting

- You can include a maximum of five authors (including yourself) 


\section{Neurology}

\section{Antiplatelets vs anticoagulation for dissection: CADISS nonrandomized arm and meta-analysis}

Louis R. Caplan and Hugh S. Markus

Neurology 2013;80;970-971

DOI 10.1212/01.wnl.0000427910.00596.db

\section{This information is current as of March 4, 2013}

\section{Updated Information \& Services}

References

Permissions \& Licensing

Reprints including high resolution figures, can be found at: http://n.neurology.org/content/80/10/970.2.full

This article cites 4 articles, 3 of which you can access for free at: http://n.neurology.org/content/80/10/970.2.full\#ref-list-1

Information about reproducing this article in parts (figures,tables) or in its entirety can be found online at:

http://www.neurology.org/about/about_the_journal\#permissions

Information about ordering reprints can be found online: http://n.neurology.org/subscribers/advertise

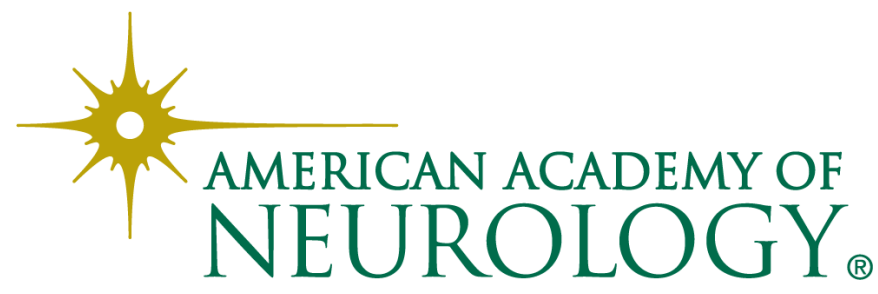

